\title{
Euthanasia in SA - sacrificing one to render many vulnerable?
}

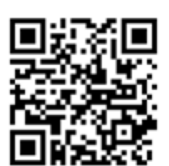

The 'sacred' value of autonomy in euthanasia and assisted suicide is not absolute, because people change their minds - while passing enabling laws 'holds grave consequences' for both individuals and society. This was the view of Dr Tom Angier of the University of Cape Town (UCT)'s Department of Philosophy, who contended that the 'sacred trilogy' of values, compassion, dignity and autonomy in the euthanasia debate would be undermined by a euthanasia-practising regime.

Angier was debating with his UCT colleague Prof. David Benatar of the Bioethics Centre in the Department of Philosophy on campus on 18 August on the potential implications of recent local legal developments on euthanasia and physicianassisted suicide (PAS). Benatar had asked Angier how existing South African (SA) law (rendering either means of death illegal) aided autonomy in a scenario where two people were in an appalling and unbearable physical condition and one wanted to 'carry on' while the other had 'had enough. 'The law enables you to express your wish and precludes me; how is that aiding autonomy?' he asked.

Angier said there wasn't enough time to give several frightening examples of cases in the Netherlands, Belgium and Switzerland, where the law conditionally favoured PAS and euthanasia. However, granting just one case on the grounds of mental suffering, for example (notoriously difficult to quantify), would be 'one case too many', not to mention the suffering and loss to family members 'when a person says they can't take it any more', he countered. 'This needs a communal and sustaining response, not simply changing the law [in SA] and getting a quick fix; he added. He cited Holland's 42 cases of euthanasia involving psychiatric illness (where therapies were no longer working) in 2013, and a 62-year-old civil servant who appealed against a tribunal that turned down his PAS application - only for him to find two supportive doctors who helped him to win his appeal. 'We also have non-voluntary (but conditional) euthanasia practised on babies with spina bifida in Holland. Out of free will - everyone has access, no questions asked. This is not a paranoid fear, though it's worthless to appeal to the law to block this kind of development because it's the law itself that embodies the slippery slope and has failed to safeguard people [in Holland], he said.

\section{'Slippery slope' concerns}

Earlier Chris Fisher, of the Faculty of Law and Department of Philosophy at UCT, sketched the status of existing law and developments in SA v. several Benelux countries, Switzerland, the USA and Canada, where pro-euthanasia and PAS legislation or judgments exist. Giving input on the 'slippery slope' concerns of anti-euthanasia legislation protagonists during the debate, Fisher said there was empirical evidence of increased terminations of pregnancy, while neonatal euthanasia declined in Holland in the 5 years since the publication of the 'Groningen Protocol' (which helps identify situations in which neonatal euthanasia might be appropriate). A comprehensive study found that 'neither the prediction that this would be the first step on a slippery slope, nor the prediction of complete transparency and legal control became true. Instead, we experienced a transformation of the healthcare system after antenatal screening policy became a part of antenatal care. ${ }^{[1]}$ The Netherlands was the first country in the world to legalise euthanasia in adults, and more recently neonatal euthanasia for severely defective newborn babies became legal under very narrowly defined circumstances.

\section{A binding precedent}

In SA, the Supreme Court's granting of individual PAS status to a terminally ill Cape Town advocate, Robin Stransham-Ford, in April this year set a binding precedent for Gauteng Province and was 'legally persuasive' in other provinces. Judge $\mathrm{H} \mathrm{J}$ Fabricius strongly recommended that existing law be developed to bring it into line with the Constitution, adding that other applicants with similar conditions could approach the courts for rulings. He stressed, however, that existing law pertained. The judge said that Stransham-Ford, who was suffering from terminal cancer with only weeks to live, was highly qualified, 'of vast experience' in the legal profession, and knew exactly what he required and why. The applicant was psychologically assessed and found to have no cognitive impairments: 'in fact he impressed as being totally rational. He had a good understanding and appreciation of the nature, cause and prognosis of his illness, plus the clinical, ethical and legal aspects of assisted suicide. Stransham-Ford, who died just hours before the ruling was made, argued in papers before the court that there was no logical distinction between withdrawing treatment to allow the natural process of death, and physician-assisted death, labelling this distinction 'intellectually dishonest'. Judge Fabricius said that while there was 
'much to be said' for this view, he would 'leave it to the philosophers' and confine himself to the constitutional debate.

\section{Intrinsic and attributed human dignity}

Angier told a packed Groote Schuur Hospital lecture theatre audience that distinguishing between intrinsic human dignity (which was inviolable) and attributed dignity (which came 'in degrees') was critical to the debate. 'As we get older we need help, become more dependent. We are fed, helped to go to the toilet; we suffer a loss of intrinsic dignity. What we can learn from this distinction is that the whole debate is dominated by attributed dignity. We all suffer this as we get older ... for some that loss is a lifelong truth, particularly the disabled - that's why the disabled are almost always against any liberalisation of the law on euthanasia, he argued. The idea that if you fell below a certain threshold of functioning you were living an undignified life, and that by giving people the right to kill themselves or be killed you were upholding their dignity, was 'leading us seriously astray'. There were already documented changes in attitudes in the Netherlands since the law outlawing euthanasia there changed, he said, citing the case of a person whose partner was disabled being asked why he was being kept alive.

'It's perfectly consistent with one's intrinsic dignity to let death take its natural course in the context of palliative care [PC]. What goes against this is [the idea] that if you're upholding dignity, you must kill. That's untrue and threatens all of us, especially the most vulnerable.'

\section{Palliative care}

Dr Liz Gwyther, convenor of programmes in palliative medicine at the School of Public Health and Family Medicine at UCT (and President of the World Palliative Care Association), said that PC affirmed life and regarded dying as a normal process. PC neither hastened nor postponed death, and euthanasia was anathema to it. She said the most compelling argument people had for wanting the choice to end their lives was 'the fear and imaginings of how dreadful the experience of dying will be'. Instead of the choice being either unbearable pain or euthanasia, the ethical and compassionate response should be effective pain management which today could deal with over $90 \%$ of situations. 'You can escalate the dose of morphine to titrate it against the patient's pain. Constipation is the only lasting long-term side-effect.' She said it was a little-known fact that Stransham-Ford had recently begun PC when the ground-breaking court ruling was made, rendering the facts upon which the ruling was based no longer true. PC enhanced a person's autonomy and dignity through attitude, behaviour, compassion and dialogue while successfully managing their pain.

One questioner juxtaposed Oregon, where just $0.3 \%$ of all deaths were a result of PAS since its Death with Dignity Act was passed in 1997, with SA, where just $4 \%$ of South Africans had access to PC, asking 'are we not missing context here?' (In Oregon, as Fisher explained, terminally ill, mentally competent adult residents with less than 6 months to live may request a script for life-ending medication under strictly monitored conditions.) Benatar agreed that context was 'crucial', but said the absence of euthanasia in SA had not exercised anybody to provide more PC. Instead the prospect of this extreme option 'may actually wake somebody up to the lack of care', he emphasised. He proposed the introduction of a 'sunset clause' in local euthanasia legislation as among the safeguards against abuse. Angier wryly said that it was influential philosophers who were at 'the forefront of the wrong side of this debate', citing several overseas authors.

\section{Racial and cultural variables}

Asked to address the racial and cultural disparities in attitudes towards euthanasia, Benatar said there might be some cultural variables on mental illness (for example), but this was not a racial question. 'We're all sentient beings who suffer in this way', he added. Angier said most of the pressure for PAS and euthanasia came from the white, educated, middle-class sector. 'They tend to be white, well-off and worried. There are some sociological grounds to think that those worries are not as prevalent in black communities where there are ten times stronger community bonds and strong spiritual resources,' he said.

The State intends to appeal to the Supreme Court of Appeal against the Stransham-Ford ruling, which may eventually be heard by the Constitutional Court.

\section{Chris Bateman}

chrisb@hmpg.co.za

S Afr Med J 2015;105(7):801-802. DOI:10.7196/SAMJnew. 8760

\footnotetext{
1. Verhagen AAE. J Med Ethics 2013;39:293-295. [http://dx.doi. org/10.1136/medethics-2013-101402]
} 